\title{
PELAKSANAAN KEPEMIMPINAN SEKOLAH TINGGI ILMU SOSIAL DAN ILMU POLITIK (STISIPOL) IMAM BONJOL PADANG
}

\author{
Vivi Puspita Sari \\ Universitas Putra Indonesia YPTK Padang \\ Email : vivipuspitasari@upiyptk.ac.id
}

\begin{abstract}
Abstract- On the basis of preliminery field observatioan, the researcher noticed that the head of STISIPOL Imam Bonjol Padang was neither administrativel not academically capable to manage the institution. This condition may not continue should the STISIPOLwant to change institution to a better and modern academic human resource. The researce put its focus on how the head of STISIPOL behaved in the process of decision - making, one of the key aspect of management. The specific research question read follow, a). how the head of STISIPOL Imam Bonjol Padang behavedin decision making, b). what types of reactions of response were given by the academic and administrative staff toward leadership behaviour, c). what problems or handicaps were faced by the head of STISIPOL. This research was conducted by applying qualitative approach. In conclusion the research dare to say that it will be very hard to for STISIPOL Imam Bonjol Padang to change and improve unless the inner structure of personnel is revitalized including the change in the policy of academic staff recruitment.
\end{abstract}

Keyword: Leadership, administrative institution.

\section{PENDAHULUAN}

Pemerintah pada dasarnya telah berupauya meningkatkan mutu sumber daya manusia sebagai realisasi pembangunan termasuk dalam bidang pendidikan, karena tidak akan mungkin pengembangan mutu sumber daya manusia tanpa memperbaiki mutu Pendidikan.UU No. 20 Tahun 2003 tentang Sistem Pendidikan Nasional khususnya Pasal 1 ayat 1 telah mengatur bahwa Pendidikan adalah usaha sadar terencana untuk mewujudkan suasana belajar dan proses pembelajaran agar peserta didik secara aktif mengembangkan potensi dirinya untuk memiliki kekuatan spiritual, keagamaan, pengendalian diri, kepribadian, kecerdasan, akhlak mulia serta keterampilan yang diperlukan dirinya, masyarakat, bangsa dan negara. UU No. 22 Tahun 2003 tentang System Pendidikan Nasional pada BAB II Pasal 3 juga bisa dilihat bahwa Pendidikan nasional berfungsi mengembangkan kemampuan dan membentuk watak serta peradaban bangsa yang bermartabat dalam rangka mencerdaskan kehidupan bangsa, bertujuan untuk berkembangnya potensi peserta didik agar menjadi manusia yang beriman, bertaqwa pada Tuhan YME, berakhlak mulia, sehat, berilmu, cakap, kreatif, mandiri dan menjadi warga negara yang demokratis serta bertanggung jawab. Perguruan tinggi sebagai salah satu sub system Pendidikan Nasional juga didesak untuk berubah dan beradaptasi dengan situasi baru. Perubahan mendorong perguruan tinggi untuk memperbaiki kinerja yang lebih efektif dan mengembangkan sumber daya yang ada untuk mencapai tujuan perguruan tinggi tersebut. Generasi muda harus dipersiapkan melalui Pendidikan yang bermutu, karena dengan adanya sumber daya manusia yang bermutu dipersiapkan untuk calon-calon pemimpin, yang dimaksud disini adalah sumber daya manusia yang mampu bersaing dalam dunia kerja regional dan global. 
Kepemimpinan merupakan suatu yang sangat mempengaruhi sebuah organisasi. Suatu organisasi akan berhasil atau gagal sebagian besar ditentukan oleh kepemimpinan. Pimpinanlah yang bertanggung jawab atas segala kegagalan pelaksanaan suatu pekerjaan yang mendudukkan posisi pemimpin dalam sebuah organisasi pada posisi yang terpenting. Kepemimpinan sangat dibutuhkan oleh manusia, karena didalamnya terdapat keterbatasan dan kelebihan-kelebihan tertentu pada manusia. Pada dasarnya kepemimpinan harus tahu dengan apa yang ingin dicapai, mengerti jalan untuk menuju ketujuan yang telah ditentukan serta menunjukkan jalan tersebut secara bersama-sama terhadap orang-orang yang dipimpinnya.

STISIPOL Imam Bonjol Padang merupakan salah satu perguruan tinggi swasta dikota padang yang telah berdiri semenjak 19 februari 1962. STISIPOL Imam Bonjol Padang memiliki dua jurusan yaitu administrasi negara dan imu pemerintahan. Berdasarkan grand tour yang peneliti lakukan terlihat persoalan-persoalan yang berkaitan dengan kekompakan tim, prosedur dalam pengambilan keputusandan trasnparan dalam pengambilan kebijakan. Persoalan-persoalan tersebut berpengaruh terhadap perkembagan STISIPOL itu sendiri. Dalam hal ini terlibat antara lain pertumbuhan jumlah mahasiswa yang tidak signifikan, kondisi ruangan belajar dan lingkungan yang tidak kondusif seperti kursi, meja, in-focus yang tidak memadai ditambah dengan ruangan yang tidak nyaman serta perpustakaan yang belum memadai. Kondisi diatas diperkuat lagi dengan hasil wawancara pendahuluan yang peneliti lakukan dengan dosen sekaligus Ketua III, dosen luar biasa, serta dosen kopertis dan terungkap bahwa ketua STISIPOL pada dasarnya tidak mau menerima kritikan dan masukan dari dosen-dosen atau pegawai lainnya dan koordinasi dengan Ketua I dan Ketua II juga tidak ada sehingga sering terjadi perselisihan antara dosen dan ketua.

Pada saat dilaksanakan grand tour juga terungkap bahwa karyawan atau pegawai administrasi tidak datang kekampus setiap hari, sehingga kampus hanya diisi oleh mahasiswa, serta dosen-dosen yang akan melakukan aktivitas perkuliahan, hal lain yang terungkap bahwa karyawan atau pegawai administrasi yang tidak adatang setiap hari membuat mahasiswa terbengkalai dalam urusan administrasi mereka, sebagai contoh adalam penerimaan mahasiswa transfer dari sekolah lain hanya mendaftar kepada mahasiswa yang direkrut langsung menjadi pegawai. Baik dosen maupun karyawan sebagian besar mengeluhkan terhadap kebijakan yang diambil misalnya honor yang jauh dari standar. Tidak adanya teguran atau sanksi bagi pegawai yang tidak dating dalam melaksanakan tugas dan tanggung jawab seperti yang telah penulis paparkan diatas ketika pegawai tidak datang ke STISIPOL.

Persoalan lain yang terlihat dari grand tour yang dilakukan adalah keputusan yang sering berubah-rubah misalnya ketika membuat jadwal perkuliahan semester baru, ketua STISIPOL meminta kepada bawahannya untuk menelepon kesediaan dosen yang akan mengajar dan hal ini tidak dilakukan oleh bawahan karena menurut bawahan sebaiknya jadwal perkuliahan dibuat dengan meninjau jadwal kuliah dosen diluar STISIPOL atau dosen luar biasa atau dosen kopertis dan kemudian dibuat jadwal perkuliahan yang efektif dan jadwal yang telah dibuat terkadang bisa dirubah begitu saja oleh ketua STISIPOL tanpa adanya pembicaraan terlebih dahulu. Sebagai salah satu perguruan tinggi swasta di kota padang STISIPOL yang memiliki dosen luar biasa dan dosen kopertis sering tidak datang dalam memberikan perkuliahan dan keadaan ini tidak dicarikan jalan keluarnya oleh ketua STISIPOL, dengan adanya kejadian ini peneliti sering mendengar ocehan mahasiswa yang merasa dirugikan karena mereka merasa membuang waktu yang bisa mereka gunakan untuk hal yang lain. 


\section{METODOLOGI}

Penelitian ini dilakukan di Sekolah Tinggi Ilmu Sosial dan Ilmu Politik (STISIPOL) Imam Bonjol Padang. Sebagaimana yang dikemukakan oleh para ahli penelitian Bogdan, Spradley, Milles, Huberman, Lincoln Guba dalam Agustiar (2008:5) terdapat tiga elemen pada sebuah lokasi penelitian yang akan diteliti, 1) ada tempat atau lokasi (place) dimana orang-orang melakukan aktivitas, 2) ada pelaku (actor) kegiatan ditempat tertentu, 3) ada aktivitas (activities) yang dilakukan oleh actor. Situasi social ini terjadi disekolah, dimana personil STISIPOL Imam Bonjol sebagai actor yang akan diteliti sebagai pelaksana Pendidikan. Sesuai dengan focus penelitian, maka lokasi penelitian yang dipilih untuk penelitian ini adalah STISIPOL Imam Bonjol Padang. Peneliti memilih tempat penelitian pada sekolah tinggi ini dengan pertimbangan sebagai berikut: 1). STISIPOL tidak mengalami perubahan kearah yang lebih baik dari tahun ketahun yang dilihat dari segi kualifikasi pegawai, jumlah mahasiswa, sarana belajar, 2). Peneliti merupakan tenaga pengajar sehingga dengan sendirinya peneliti dapat dengan mudah untuk masuk kesituasi penelitian.

Salah satu tujuan utama penelitian kualitatif adalah memecahkan masalah dengan cara memperoleh informasi yang akurat dan objektif. Hal ini sangat penting artinya karena kesimpulan penelitian hanya akan dapat dipercaya apabila yang menjadi sumber (informan) juga dapat dipercaya, dengan demikian tahapan penentuan informan dalam penelitian ini merupakan langkah yang sangat strategis terhadap kualitas informasi yang diperoleh. Kesalahan dalam memilih informan akan membawa dampak terhadap validitas dan reabilitas suatu temuan penelitian. Untuk itu proses pemilihan informan dalam penelitian ini adalah langkah penting untuk dicermati. Penelitian kualitatif memiliki konsep tersendiri dalam menentukan subjek penelitian, yang mana berhubungan dengan apa dan siapa yang diteliti. Pada penelitian ini, peneliti memilih informan memakai tekhnik sampling, karena sampling lazim dipakai dalam jumlah populasi besar sehingga tidak memungkinkan atau berat bagi peneliti untuk meneliti individua tau objek yang ada dalam populasi. Sehubungan dengan bentuk Teknik sampling, maka pada penelitian ini peneliti memilih informan dengan Teknik "purposive sampling" yaitu Teknik pemilihan informan dengan pertimbangan tertentu. Dengan Teknik purposive sampling ini peneliti memilih informan berdasarkan keterwakilan yang pengetahuannya tentang objek penelitian tidak diragukan diantaranya sebagai berikut :

1. Ketua STISIPOL Iman Bonjol ( ketua, Pembantu Ketua I, Pembantu Ketua II, Pembantu Ketua III)

2. Dosen Tetap Yayasan Imam Bonjol Padang

3. Dosen Kopertis

4. Dosen Luar Biasa

5. Pegawai

6. Mahasiswa STISIPOL

7. Alumni STISIPOL

Informan dengan latar belakang dalam penelitian dimanfaatkan untuk memberikan informasi tentang situasi dan kondisi latar penelitian Lexi J. Moleong (2002:90), oleh sebab itu seorang informan harus memiliki banyak pengalaman tentang latar belakang penelitian.

Teknik dan alat pengumpulan data yang peneliti gunakan disini bukanlah angket atau kuisioner namun peneliti sediri yang menjadi instrument utama dalam pengumpulan data dan informasi. Guna mendapatkan data yang diharapkan dalam penelitian ini, peneliti menggunakan beberapa Teknik yang dianjurkan dalam penleitian kualitatif seperti yang diuraikan dibawah ini: 
1. Observasi. Teknik obsevasi yang digunakan dalam dua tahap yaitua melalui kegiatan observasi pendahuluan atau grand tour, dan hasil deskripsi observasi lanjutan yang dilakukan secara mendalam dan terfokus, sesuai dengan pokok masalah yang diteliti

2. Wawancara. Jenis wawancara yang digunakan dalam penenlitian ini adalah wawancara terstruktur dan wawancara tidak terstruktur. Semua informasi berupa jawaban, pikiran, atau pendapat yang diberikan oleh informan akan dicatat sebaik mungkin baik dalam kalimat langsung maupun tidak langsung yang mengandung konotasi sendiri diharapkan tidak lupa atau tertinggal. Guna menguji keabsahan kedekatan atas permasalahan yang diteliti, jawaban dari informan objek penelitian dilakukan lagi dengan pengujian informasi tersebut terhadap informan yang telah ditentuakn seperti dosen Yayasan, dosen tetap, dosen kopertis dan pegawai administrasi serta alumni

3. Studi Dokumentasi. selain observasi dan wawancara, studi dokumentasi dapat digunakan untuk melengkapi data penelitian. Studi dokumentasi dilakukan dalam penelitian ini melengkapi informasi yang diperoleh dari Teknik observasi dan wawancara. Adapun informasi yang hendak didapat pada studi dokumentasi berbetuk data STISIPOLImam Bonjol Padang yang bias dilihat dari akreditasi kampus, visi dan misi, aturan-aturan senat dan sebagainya.

Teknik penjaminan dan keabsahan data dalam penelitian ini peneliti pakai dengan menggunakan trianggulasi sumber data. Trianggulasi sumber data adalah Teknik pemeriksaan keabsahan data yang memanfaatkan sesuatu diluar data itu untuk keperluan pengecekan dan sebagai pembanding terhadap data itu. Trianggulasi sumber data yang peneliti gunakan dalam penelitian ini adalah: 1) membandingkan apa yang dikatakan orang didepan umum, dengan apa yang dikatakannya secara pribadi, 2) membandingkan tentang apa yang dikatakan orang tentang situasi penelitian dengan apa yang dikatakannya sepanjang waktu, 3) membandingkan hasil wawancara dengan isi suatu dokumen yang berkaitan.

Pendekatan penelitian yang peneliti gunakan dalam penelitian ini adalah metode penelitian kualitatif dengan pendekatan indiktif. Berdasarkan uaraian diatas dapat dipahami bahwa alasan menggunakan pendekatan kualitatif dalam penelitian ini adalah memungkinkan peneliti dapat membuat dan menyusun konsep-konsep yang hakiki yang dialami oleh masyarakat secara nyata dalam kehidupan mereka. Peneliti meyakini bahwa dengan menggunakan metiode kualitatif ini akan sangat membantu peneeliti dalam mengungkapkan tentang bagaimana kepemimpinan Ketua STISIPOL Imam Bonjol Padang.

Taknik Analisa data yang peneliti gunakan adalh interprestasi etik dan interprestasi emik. Interprestasi etik yang peneliti gunakan bertujuan mengelompokkan data yang peneliti peroleh secara sistematis yang dapat dibandingkan, dipelajari, diuraikan setelah menemukan data baru, kemudian interprestasi emik yang mana peneliti gunakan dengan tujuan mengungkapkan informasi atau pendapat yang disampaikan oleh informan. Dalam menganalisis data penelitian, peneliti menggunakan langkah-langkah sebagai berikut:

1. Menelaah seluruh data yang diperoleh melalui wawancara yang ditulis dalam arsip, dokumen, gambar, photo sebagai dokumentasi baik yang didapat melalui informan tempat penelitian. Data yang peneliti kumpulkan berhubungan dengan kepemimpinan dalam aspek pengambilan keputusan.

2. Reduksi data (data reduction). Dalam penelitian ini dilakukan dalam bentuk proses menggolongkan, mengarahkan, mengesampingkan data yang tidak perlu dan 
mengorganisasikan, pengeditan, pemusatan perhatian dan penyederhanaan data. Reduksi data merupakan proses berfikir sensitive yang memerlukan kecerdasan dan keliasan serta kedalaman wawasan yang baik

3. Penyajian data (data display). Kegiatan ini dilakukan setelah melakukan reduksi data dan menganalisis data yang bertujuan untuk menampilkan data yang telah diperoleh. Data yang diperoleh diharapkan dapat memberikan gambaran yang ditemukan peneliti sesuai apa yang dikatakan dengan yang dilakukan

4. Menarik kesimpulan dan verivikasi (Conclusion drawing/verification). Menarik kesimpulan merupakan kegiatan yang dapat melihat validitas selama melakukan penelitian sedangkan verifikasi bertujuan untuk menarik kesimpulan

\section{ANALISIS}

Temuan Umum

STISIPOL Imam Bonjol Padang terletak dikota Padang Kecamatan Padang Utara tepatnya di Jalan Koto Tinggi Padang. Yayasan STISIPOL Imam Bonjol Padang ini didirikan tanggal 19 februari 1962 akta notaris Hasan Qalbi No. 34 terdaftar di Departemen Perguruan Tinggi dan Ilmu Penegtahuan di Jakarta tanggal 27 September 1965 dan pada Kopertis Wilayah I Medan pada tanggal 20 mei 1975. Yayasan Imam Bonjol padang disponsori oleh Bapak Drs. Azhari, Burma Burhan SH, Lim Swan Hong, Hadis Didong dan khususnya bergerak dalam bidang Pendidikan. Pada tanggal 27 september 1965 dengan surat keterangan terdaftar NO. 129/B-Swt/P/1965 Fakultas sospol Imam Bonjol terlah dinyatakan terdaftar untuk tingkat sarjana muda, dan selanjutnya tangal 12 Agustus 1972 pernyataan terdaftar tersebut diperluas sehingga meliputi tingkat sarjana muda dan sarjana lengkap. SK No. 29 Tahun 1975 tanggal 9 Juli 1975 Fakultas SOSPOL diganti Namanya dengan STISIPOL Imam Bonjol Padang.

Kegiatan pembelajaran di STISIPOL Imam Bonjol Padang berlangsung setiap hari mulai dari hari senin sampai hari minggu, senin sampai jumat dimulai pada pukul 16.15 WIB sampai pukul 20.30 WIB sedangkan hari sabtu dan minggu pembelajaran dimulai pukul 08.00 WIBsampai pukul 16.00 WIB. Sebelum melaksanakan kegiatan pembelajaran pada umumnya berkumpul dipekarangan sekolah tinggi dan sebagian lagi duduk-duduk di kantin yang berada di samping ruangan kelas belajar. Selama peneliti melakukan observasi secara langsung masih terlihat bahwa dosen dan staf administrasi terlihat datang paling cepat pukul 17.30 WIB dan pulang pukul 20.30 WIB. Selama melakukan penelitian ini terlihat bahwa dalam beberapa tahun belakangan tidak pernah dilakukan kemah bakti mahasiswa (KBM), barulah pada bulan januari 2010 di laksanakan KBM di Sei Sapiah Padang yang dilaksankan tiga hari lamanya. Selama kegiatan KBM ini dilakukan mahasiswa diwajibkan melakukan KKL berupa penanaman pohon jati di perumahan penduduk dan penggalian saluran air bersih. Kegiatan KKL yang seharusnya dilaksanakan oleh setiap perguruan tinggi selama ini ternyata belumlah berjalan maksimal di STISIPOL Imam Bonjol Padang.

STISIPOL Imam Bonjol Padang dalam menghadiri undangan seminar baik ditingat local maupun nasional hanya di ikuti ole $\mathrm{h}$ Ketua STISIPOL dan Pembantu Ketua III. Kegiatan ini merupakan kegiatan yang dilakukan di luar sekolah tinggi dan dapat dihadiri secara bergiliran oleh dosen /pengajar. Kegiatan lain seperti kegiatan di bidang kesenian dan olahraga tidak terlihat perkembangannya selama ini, walaupun banyak prestasi-presatasi mahasiswa yang seharusnya disalurkan. Tidak adanya kegiatan ini membuat mahasiswa terpaksa untuk tidak berperan serta dalam mengembangkan dan meningkatkan potensi sekolah tinggi. 


\section{Visi dan Misi STISIPOL Imam Bonjol Padang}

Visi STISIPOL Imam Bonjol Padang adalah mengasilkan lulusan yang berpengetahuan komprehensif tentang ilmu social dan ilmu politik, terutama dalam bidang administrasi negara dan ilmu pemerintahan, tanggap terhadap permasalahan-permasalahan dan perkembangan yang terjadi sebagai dampak globalisasi, mampu bersaing dalam dunia kerja di tingkat local dan nasional. Misi dari STISIPOL Imam Bonjol Padang adalah:

1. Menyelenggarakan program Pendidikan dan pengajaran yang berbasis pada ilmu social dan ilmu politik, terutama ilmu administrasi negara dan ilmu pemerintahan

2. Mengembangkan sikap tanggap permasalahan dan perkembagan yang terjadi sebagai dampak globalisasi dalam rangka membantu pemecahan masalah yang terjadi, baik ditingkat local maupun nasional. Memberikan kemampuan professional dalam menghadapi persaingan dunia kerja

\section{Temuan Khusus}

Pelaksanaan kepemimpinan di STISIPOL Imam Bonjol Padang ditemukan bahwa pimpinan STISIPOL Imam Bonjol Padang tidak mampu untuk mempengaruhi bawahannya. Hal ini dapat dilihat bahwa pimpinan selalu dibantah oleh bawahan baik dosen tetap Yayasan, dosen kopertis, maupun dosen luar biasa. Dalam pelaksanaan kepemimpinan seorang pemimpin harus bias memperjuangkan kepentingan bawahannya dan mewujudkan sebagian besar keinginan bawahannya. Di STISIPOL Imam Bonjol Padang masih banyak sekali harapan yang ingin dicapai oleh bawahan namun belum terwujud. Ketua sebagai pucuk pimpinan terlihat belum bias menjadi panutan dan contoh bagi bawahannya terutama sekali dalam hal kemajuan sekolah tinggi yang dipimpin agar tercapainya tujuan yang telah ditetapkan. Pada dasarnya kepemimpinan dapat meyentuh segala sapek kehidupan, yang mana dalam arti lain pimpinan dapat mempengaruhi moral serta kepuasan kerja, keamanan, kualitas kehidupan kerja dan terutama tingkat prestasi sekolah tinggi.

Kepemimpinan STISIPOL Imam Bonjol Padang terlihat belum bisa mewujudkan hubungan yang harmonis dengan bawahannya, kebutuhan akan minat dan kebutuhan yang dibutuhkan oleh bawahan belum dapat diwujudkan secara maksimal oleh pimpinan dalam mencapai tujuan organisasi yang di inginkan. Berdasarkan temuan dilapangan terlihat juga bahwa hubungan antara pimpinan dengan pemimpin yang lain juga belum terlihat harmonis, sebab masih adanya adu argument yang terkadang sampai meruncing dan menjadi masalah yang lebih besar. Pembantu ketua tidak berperan secara signifikan dalam hal kepemimpinan, karena terlihat bahwa antara ketua dengan pembantu ketua memiliki karakter yang bertolak belakang. Jika dilihat lebih jauh kepemimpinan yang diawali dengan tindakan mempengaruhi anggota dan diakhiri dengan pencapaian tujuan serta kepuasan anggota juga belum bias berubah secara signifikan, hal ini terlihat ketika bawahan masih banyak mengeluh dengan kepemimpinan yang sedang berjalan, namun ketua dalam mengadakan rapat mau dan masih bisa menerima saran serta masukan walaupun ketua sebagai pimpinan bersikeras dengan pendapatnya. Dalam pelaksanaan kepemimpinan ini juga dapat dilihat bahwa kepemimpinan STISIPOL Imam Bonjol Padang sudah mampu mempengaruhi bawahannya bekerja secara sukarela dalam mencapai tujuan organisasi, hal ini terlihat pendapatan yang dicapai bawahan jauh dibawah standar penggajian dan peningkatan kesejahteraan hidup pegawai.

Melengkapi hasil temuan penelitian yangtelah diuraikan di atas, peneliti merasa perlu untuk menjelaskan bahasan yang berkaitan dengan dengan pelaksanaan kepemimpinan di 
STISIPOL Imam Bonjol Padang yaitu kepemimpinan Di STISIPOL Imam Bonjol Pdadang trelihat bahwa pimpinan belum bias mempengaruhi bawahannya dalam berbagai hal, namun mampu mempertahankan bawahannya dalam mengikuti apapun yang dilakukannya. Sebagaimana yang telah dijelaskan oleh Winardi (1979:327) bahwa:

Kepemimpinan adalah adanya hubungan dimana satu orang yaitu pimpinan mampu mempengaruhi pihak lain untuk bekerjasama secara sukarela dalam mengerjakan tugas-tugas yang berhubungan dengan pencapaian tujuan yang diinginkan pemimpin yang mana memiliki dua tipe pengaruh kepemimpinan yaitu prestasi pimpinan itu sendiri yang secara langsung mempengaruhi tingkat pekerjaan kelompok serta terdapat kelakuan pimpinan guna mempengaruhi kehidupan kelompok dan kepuasan anggotanya.

Dari penjelasan diatas dapat dilihat bahwa ternyata bawahan baik dosen dan pegawai masih bias menerima apapun yang diminta oleh pimpinan tanpa ada perubahan sanggahan yang berarti dalam membuat sebuah perubahan. Pimpinan mampu juga untuk mempengaruhi bawahannya dalam segi kehidupan kelompok dan kepuasan anggota, walaupun banyak sekali hal-hal yang dirasakan bawahan bertolak belakang dengan apa yang diinginkan, namun bawahan masih bisa tetap menerima dan bekerja untuk melaksanakan fungsi dan tanggung jawab yang diberikan kepadanya.

\section{KESIMPULAN}

Berdasarkan hasil penelitian yang peneliti lakukakan di STISIPOL Imam Bonjol Padang diperoleh kesimpulan sebagai berikut :

1. Pelaksanaan kepemimpinan di STISIPOL Imam Bonjol Padang terlihat masih jauh dari harapan. Hubungan antara pimpinan juga terlihat kurang harmonis. Kepemimpinan di STISIPOL Imam Bonjol Padang terlihat belum bias mewujudkan hubungan yang harmonis dengan bawahannya.

2. Pengalaman berorganisasi dan memimpin juga sangat menentukan keberhasilan suatu kepemimpinan. Aspek ini juga dapat menyebabkan kepemimpinan belum optimal

\section{DAFTAR PUSTAKA}

Agustiar Syah Nur. 2008. Qualitative Research Methodology. Diktat Pascasarjana Universitas Negeri Padang

Akhiyen Nuardi. 2005. Strategi Kepemimpinan Mtsn Talaok Kecamatan Bayang Pesisir Selatan. Padang: PPS UNP

Bogdan Robert, Steven J. Tylor. 1993. Kualitatif. Dasar-dasar Penelitian Kualitatif. Surabaya. Usaha Nasional

Burhan. Bungin. 2005. Analisis Data Penelitian Kualitatif. Pemahaman Filosofis Dan Metodologis Kearah Penguasaan Model Aplikasi. Jakarta. Raja Grafindo Persada

Effendi. 2006. Kepemimpinan Kepala Sekolah MtsN Model 1 Bukittinggi. Padang: PPS UNP Hadari Nawawi. 2000. Manajemen Sumber Daya Manusia Untuk Bisnis yang Kompetitif. Yogyakarta: Bumi Aksara

Hamdan Mansoer. 1989. Pengantar Manajemen. Jakarta: P2LPTK

Hersey. Paul and Kenneth, H. Blancard.1998. Manajemen Prilaku Organisasi :Pendayagunaan Sumber Daya Manusia (Agus Dharma, pen). Jakarta: Erlangga 
Ibrahim Bafadal.2003. Manajemen Peningkatan Sekolah Dasar. Dari Sentralisasi Menuju Desentralisasi. Jakarta: Bumi Aksara

Iskandar. 2009. ,Metodologi Penelitian Kualitatif. Aplikasi Untuk Penelitian Pendidikan, Hukum, Ekonomi dan Manajemen Sosial, Humaniora, Politik, Agama, dan Filsafat. Jakarta: Gaung Persada Johannes Suprapto. 1998. Teknik Pengambilan Keputusan. Jakarta: Rineka Cipta Kartini Kartono. 2006. Pemimpin dan Kepemimpinan. Jakarta: raja Grafindo Persada K. Permadi. 1996. Pemimpin Dan Kepemimpinan Dalam Manajemen. Jakarta: Rineka Cipta Lexi J. Moleong.2002. Metodologi Penelitian Kualitatif. Jakarta: Bumi Aksara M.J Morrus. 1997. The First Manager. Kunci Sukses Menjadi Manajer Handal. Jakarta: Gramedia Pustaka Utama Miftah Thoha. 2004. Kepemimpinan Dalam Manajemen. Jakarta: Raja Grafindo M. Ngalim Purwanto. 2004. Administrasi Dan Supervise Pendidikan. Bandung: PT Remaja Rosdakarya Oemar Hamalik. 2000. Psikologi Manajemen. Bandung: Trigenda karya Fakultas Ilmu Pendidikan Universitas Negeri Padang. 2000. Pengambilan Keputusan. Padang PP No. 19 Tahun 2005.2006. Tentang Standar Nasional Pendidikan. Jakarta: Sinar Grafika Spradley, James.P. 1980. Participant Observation. New York. Holt, Rinehart dan Winston Stoner, James A.F, Freeman, R. Edward, Gilbert. 2003. Manajemen. Penerjemah Alexander Sindoro. Jakarta: PT. Indeks

Sugiyono.2005. Memahami Penelitian Kualitatif. Bandung: Alfabeta T. Tani Handoko.2000. Manajemen. Yogyakarta: BPF

Terry.George R dan Rue L.W.1993. Dasar-Dasar Manajemen. Penerjemah G.A Ticoalu. Jakarta: Bumi Aksara

Timpe, A. Dale. 1993. Seri Ilmu dan Seni Manajemen Bisnis. Kepemimpinan. Jakarta: Gramedia Pustaka Utama

UU No. 20 Tahun 2003.2004. Tentang System Pendidikan Nasional. Jakarta: Sinar Grafika Wahyudi. 2009. Kepemimpinan Kepala Sekolah Dalam Organisasi . Bandung: Alfabeta Wahjosumidjo. 1999. Kepemimpinan Kepala Sekolah Tinjauan Teoritik dan Permasalahannya . Jakarta: Raja Grafindo Persada

Winardi. 1979. Asas-Asas Manajemen. Bandung: Alumni

Gusman, A. P. (2019). ANALISA PERANCANGAN DAN IMPLEMENTASI PEMESANAN SECARA ONLINE BERBASIS COSTUMER RELATIONSHIP MANAGEMENT (CRM). MAJALAH ILMIAH, 26(1), 7-13.

Zulkadri. 2001. Kepemimpinan Kepala Sekolah Dasar Dalam Upaya Peningkatan Mutu Proses Belajar Mengajar di SD. 03. Batuang Kota Padang . PPS UNP 